\title{
Antioxidant and Free Radical Scavenging Capacity of Crude and Refined Oil Extracted From Azadirachta indica A. Juss.
}

\author{
Sunday O. Okoh ${ }^{1,2}$, Ade O. Oyewole ${ }^{1}$, Ruth O. Ishola ${ }^{1}$, Adenike D. Odusote ${ }^{1}$, Omobola O. Okoh ${ }^{2}$, Chima C. Igwe ${ }^{1}$ \\ \& Gloria N. Elemo ${ }^{3}$ \\ ${ }^{1}$ Department of Chemical Fibre and Environmental Technology, FIIRO, Lagos, Nigeria \\ ${ }^{2}$ Department of Chemistry, University of Fort hare, Eastern Cape, South Africa \\ ${ }^{3}$ Department of Food Technology, FIIRO, Lagos, Nigeria \\ Correspondence: Sunday O. Okoh, Department of Chemical, Fibre and Environmental Technology, FIIRO, Lagos, \\ Nigeria. Tel: 234-802-341-6380. E-mail: Sunday.okoh@fiiro.gov.ng, sunnyokoh2003@yahoo.com
}

Received: December 12, 2014 Accepted: December 23, 2014 Online Published: February 8, 2015

doi:10.5539/ijb.v7n2p78 URL: http://dx.doi.org/10.5539/ijb.v7n2p78

\begin{abstract}
Naturally nutritive and non-nutritive occurring antioxidants have been proven potent and safe for management of variety of diseases. This study investigated the antioxidant and free radical scavenging capacity of crude and refined Azadirachta indica (Neem tree) oil. The neem crude oil (NCO) was extracted from the seeds by mechanical press and degummed. The neem oil was de-pigmented with activated charcoal, and fractionated with silica gel in a capillary column. The ability of the oils to act as hydrogen/electrons donor were determined in-vitro using 2, 2-dipphenyl-1-picrylhydrazyl (DPPH), 2, 2-azinobis - (3-ethylbenzothiazolin - 6-sulfonic acid) diammonium salt (ABTS), lipid peroxyl (LP) and nitric oxide (NO) radicals scavenging assays, at different extract concentrations (0.1, $0.2,0.3$ and $0.4 \mathrm{mg} / \mathrm{mL})$. The $\mathrm{IC}_{50}$ of the $\mathrm{NCO}$ oil $(1.50 \pm 0.10 \mathrm{mg} / \mathrm{mL})$ showed that antioxidant activity is comparable to vitamin $C$ and $\beta$-carotene $(1.60 \pm 0.10$ and $1.27 \pm 0.12 \mathrm{mg} / \mathrm{mL}$ respectively) in scavenging DPPH radical. The crude neem oil exhibited superior activity against NO radical, than the refined oil and vitamin C. Generally, in the four antioxidant assays, a significant correlation existed between concentrations of the oils and percentage inhibition of the four different radicals. GC/MS analyses identified monounsaturated and saturated fatty acids, aldehydes and pentanethiol as the major compounds in the oils, these may account for their antioxidant capacity.
\end{abstract}

Keywords: Azadirachta indica, antioxidant, DPPH, nitric oxide radicals, unsaturated fatty acids

\section{Introduction}

Natural antioxidant has been proven safe and potent in reduction or inhibition of free radicals which play vital role in damaging various cellular macromolecules (Morten, Mygind, \& Rikke, 2012; Camila et al., 2013). The generation of free radicals such as superoxide $\left[\mathrm{O}_{2}{ }^{\circ}\right]$ hydroxyl $\left[\mathrm{OH}^{*}\right]$, peroxyl $\left[\mathrm{RO}_{2}{ }^{\circ}\right]$, hydroperoxyl $\left[\mathrm{HO}_{2}{ }^{\circ}\right]$, alkoxyl $\left[\mathrm{RO}^{*}\right]$, nitric oxide $\left[\mathrm{NO}^{*}\right]$ and lipid peroxyl [ $\left.\mathrm{LOO}^{\circ}\right]$ beyond the antioxidant capacity of a biological system gives rise to oxidative stress (Murray, Rodriguez, Frontera, \& Mulet, 2004). Oxidative stress has been implicated in the pathogenesis of a variety of inflammatory diseases such as arthritis, stroke, intestinal ischemia, acquired immunodeficiency syndrome (AIDS), hypertension, neurologic diseases e.g., multiple sclerosis, Alzheimer's disease, diabetes, cancers, and atherosclerosis (Sachdev, \& Davies, 2008; Mahmood, Soheila, \& Saeid, 2008; Saikat, Chakraborty, Sridhar, Reddy, \& Biplab, 2010; Mimica-Dukic, Dušan, Slavenko, Dragana, \& Branka, 2010; Okoh, Asekun, Familoni, \& Afolayan, 2014). Plants contain antioxidant compounds that function as free radical scavengers, reducing agents and quenchers of singlet oxygen formation. There have been increasing suggestions and demand for use of natural antioxidant as potential substitute for the synthetic ones (Nweze, \& Okafor, 2010; Tuttolomondo et al., 2013). The side effects of the currently available synthetic drugs pose some limitation and studies have shown that synthetic antioxidants unlike the natural analog cannot be recycled or re-used by the organism once they have donated their electron (Wang, $\mathrm{Wu}, \mathrm{Zu}, \& \mathrm{Fu}, 2008$ ). Consequently, they become harmful metabolic byproducts that increase, rather than decrease the total load of oxidative stress (Miller et al., 2005). One of the current trends in green chemistry is the utilization of plant extracts as drugs in the form of food confectionaries, disinfectants, insecticides, nutraceuticals, herbal drinks, fragrance, and supplement to prevent diseases or for health management (Morten, Mygind, \& Rikke, 2012). Azadirachta indica (Neem tree) is used in traditional medicine in many West African countries for the treatment of various human diseases. The leaf serves 
as roof in traditional houses to repel mosquitoes and aqueous extracts of the leaves are used as anti-diabetic agent and malaria treatment (Anaso \& Anaso, 2001). A. indica seed and leaf extracts are currently used in some countries especially in India as active ingredient in the manufacture of neem tea, cosmetics, insect repellents and herbal dentifrice (Okujagu, 2009). The extracts from Asian neem tree were reported to contain the active compound azadirachtin, nimbinin and nimbandiol, as well as several natural steroids (Sadeghian, \& Mortazaienezhad, 2007). The anti-malarial activity of neem has been attributed to azadirachtin, which is a limonoid compound (Mak-Mensah \& Firempong, 2011). The leaf, flower, bark and root extracts of neem tree have been reported to possess antioxidant activity (Subapriya, \& Nagini, 2005; Ghimeray, Jin, Ghimire, \& Cho, 2009; Nahak \& Sahu, 2010; Nahak, \& Sahu, 2011). One of the strong antioxidant compounds documented in the neem crude seed oil is catechin (Anokwuru, Ajibaye, \& Adesuyi, 2011). Neem oil was also reported to exhibit high percentage inhibition against DPPH radical (Ghimeray, Jin, Ghimire, \& Cho, 2009).

The crude neem oil is however very bitter and further study may be necessary to eliminate or reduce the bitter taste for wider applications (Okoh, Ahmed, Okoh, \& Igwe, 2014).There is also scanty information on the refined neem oil as well as the comparative study of the antioxidant capacity of the crude and refined (de-bittered) seed oils in variety of radicals quenching assays. Therefore, this present research was conducted to investigate the in-vitro antioxidant capacity and free radical scavenging activity of the crude seed-oil extracted from A. indica as well as the refined oil. This research is part of an ongoing study aimed at discovering oil seed with bioactive or industrial potentials either as nutraceuticals, cosmetics, soap and industrial chemicals that are indigenous to Nigeria.

\section{Materials and Methods}

\subsection{Chemicals Used}

Potassium persulfate (PPS), 2, 2-dipphenyl-1-picrylhydrazyl (DPPH) and 2, 2-azinobis-(3-ethylbenzothiazolin-6sulfonic acid) diammonium salt (ABTS) were purchased from Sigma - Aldrich St Louis, USA). Methanol was purchased from Fluka Chemicals (Buchs, Switzerland). All other chemicals used were analytical grade.

\subsection{Plant Materials and Oil Refining}

The neem crude oil was obtained from National Research Institute for Chemical Technology; Zaria (NARICT) was extracted from the seeds by mechanical press. The neem crude oil (NCO) $(200 \mathrm{~mL})$ was degummed by previously as described method (Asuquo, Etim, Ukpong, \& Etuk, 2012). It was then refined to reduce the oil crude pigment with $10 \%$ activated charcoal at $65^{\circ} \mathrm{C}$. The oil after cooling was decanted, centrifuged at $500 \mathrm{rpm}$ for $10 \mathrm{~min}$ and filtered to obtain the first refined neem oil (RNO1). Fifty percent of the RNO1 was subsequently fractionated using silica gel $5.4 \%$ in a $200 \times 1.47 \mathrm{~mm}$ column to obtain colourless de-bittered fraction of refined neem oil (RNO2).

\subsection{Gas Chromatography/Mass Spectrometry (GC/MS) and Identification of Compounds}

The GC/MS analyses of the oils were conducted on a Hewlett- Packed HP 5973 mass spectrometer interfaced with an HP 6890 gas chromatograph. The following column and temperature conditions were used; initial temperature $70^{\circ} \mathrm{C}$, equilibration time $3.00 \mathrm{~min}$, ramp $4^{\circ} \mathrm{C} / \mathrm{min}$, final temperature $240^{\circ} \mathrm{C}$; inlet: splitless, initial temperature $220^{\circ} \mathrm{C}$, pressure $8.27 \mathrm{psi}$, purge flow $30 \mathrm{~mL} / \mathrm{min}$, purge time $0.20 \mathrm{~min}$, helium gas; column: capillary, $30 \mathrm{~m} \times 0.25$ $\mathrm{mm}$ i.d; $0.25 \mu \mathrm{m}$, film thickness $0.7 \mathrm{ml} / \mathrm{min}$, average velocity $32 \mathrm{~cm} / \mathrm{sec}$; MS: EI method at $70 \mathrm{eV}$.

The oils compounds were identified by matching their mass spectra data with those of authentic standards held in the computer library (Wiley 275, New York) and by comparing the calculated retention indices with those in literature. The percentage composition was calculated from summation of the peak areas of the total oil composition (Asekun, Okoh, Familoni, \& Afolayan, 2013).

\subsection{Antioxidant Activity}

The antioxidant activities were examined by DPPH radical scavenging test, ABTS free radical decolonization assay, nitric oxide and lipid peroxyl radicals scavenging assays.

\subsubsection{DPPH Assay}

The 2,2 - diphenylpicrylhydrazyl radicals (DPPH) test of the oil was carried out as described by previous method (Okoh, Asekun, Familoni, \& Afolayan, 2011) with minor change (oils concentrations prepared in ethyl acetate). A solution of $0.135 \mathrm{~mm}$ DPPH in methanol was prepared and $1.0 \mathrm{ml}$ of this solution was mixed with $1.0 \mathrm{ml}$ of the oil prepared in ethyl acetate containing $1.0-4.0 \mathrm{mg} / \mathrm{mL}$ of the oil and standard drugs (vitamin $\mathrm{C}$ and $\beta$ carotene). The reaction mixture was vortexed thoroughly and left in the dark at room temperature for $30 \mathrm{~min}$. The absorbance of the mixture was measured spectrophotometrically at $517 \mathrm{~nm}$. Ethyl acetate was used as blank and all measurements were performed in triplicate. The ability of the oil to scavenge DPPH radical was calculated as \% inhibition using the following equation. 


$$
\% \text { inhibition }=\left\{\left(\mathrm{Abs}_{\text {control }}-\mathrm{Abs}_{\text {sample }}\right)\right\} /(\text { Abs control }) \times 100
$$

Where Abs control is the absorbance of the DPPH radical + methanol; Abs sample is the absorbance of DPPH radical + oil or standard.

\subsubsection{ABTS Assay}

In the 2, 2-azinobis-(3-ethylbenzothiazolin - 6-sulfonic acid) diammonium salt (ABTS) free radicals assay, the method of Witayapan and co-workers (Witayapan, Sombat, \& Siriporn, 2007) was adopted with minor changes (ABTS stock solution diluted in methanol). The pre-formed radical monocation of ABTS is generated by oxidation of ABTS solution ( $7 \mathrm{~mm}$ ) with $2.45 \mathrm{mM}$ potassium persulfate solution in equal amount. The mixture was allowed to react for $12 \mathrm{~h}$ in the dark at room temperature. The resulting solution $(1 \mathrm{ml})$ was diluted in $60 \mathrm{ml}$ of ethyl acetate to obtain an absorbance of $0.706 \pm 0.001$ at $734 \mathrm{~nm}$ using spectrophotometer. The ABTS radical cation solution (1 $\mathrm{ml}$ ) was added to series of oil solutions and standards drugs (vitamin $\mathrm{C}$ and $\beta$-carotene) of different concentrations $0.1-0.4 \mathrm{mg} / \mathrm{mL}$, prepared by diluting with ethyl acetate. Ethyl acetate without oil sample was used as blank. The absorbance, after $7 \mathrm{~min}$ were measured spectrophotometrically at $734 \mathrm{~nm}$. All measurements were carried out in triplicate. All measurements were carried out in triplicates. The percentage inhibitions of ABTS radical by the oils were calculated using the equation as described in the DPPH assay.

\subsubsection{Lipid Peroxidation Assay}

The Thiobarbituric acid-reactive species (TBARS) assay as described by previous method (Badmus, Odunola, \& Obuotor, 2010) was used to measure the lipid peroxide formed, using egg-yolk homogenates as lipid-rich media with a minor change (methanol used for dilution of oils instead water). Egg homogenate $(0.5 \mathrm{~mL}, 10 \%$ in distilled water, v/v) and the oils of different concentrations $1.0-4.0 \mathrm{mg} / \mathrm{mL}$ prepared by diluting with ethyl acetate were mixed in test tubes and the volume was made up to $1 \mathrm{ml}$, by adding methanol. Finally, $0.05 \mathrm{ml} \mathrm{FeSO}_{4}(0.07 \mathrm{M})$ was added to the above mixture and incubated for $30 \mathrm{~min}$, to induce lipid peroxidation. Thereafter, $1.5 \mathrm{ml}$ of $20 \%$ acetic acid ( $\mathrm{pH}$ adjusted to 3.5 with $\mathrm{NaOH}$ ) and $1.5 \mathrm{ml}$ of $0.8 \%$ Thiobarbituric acid (w/v) (prepared in $1.1 \%$ sodium dodecyl sulphate) and $0.05 \mathrm{ml} 20 \%$ trichloroacetic acid were added, the test tubes were vortexed and then heated in a boiling water bath for $60 \mathrm{~min}$. After cooling, $5.0 \mathrm{ml}$ of 1-butanol was added to each tube and centrifuged at $3000 \mathrm{rpm}$ for $10 \mathrm{~min}$. The absorbance of the organic upper layer was measured at $532 \mathrm{~nm}$. For the blank $0.1 \mathrm{ml}$ of ethyl acetate was used in place of the oil. The percentage inhibitions of lipid peroxyl radical by the oils were calculated using the equation as described in the DPPH assay.

\subsubsection{Nitric Oxide Assay}

The method described by Makhija et al., (Makhija, Aswatha, Shreedhara, Vijay, \& Devkar, 2011) was adopted. Nitric oxide radicals were generated from sodium nitroprusside solution at physiological $\mathrm{pH}$. Sodium nitroprusside $(1.0 \mathrm{~mL}$ of $10 \mathrm{~mm}$ ) was mixed with $1.0 \mathrm{~mL}$ of oil in different concentrations $1.0-4.0 \mathrm{mg} / \mathrm{mL}$ in phosphate buffer (pH 7.4). The mixture was incubated at $25^{\circ} \mathrm{C}$ for $150 \mathrm{~min}$. To $1.0 \mathrm{ml}$ of the incubated solution, $1.0 \mathrm{ml}$ of Griess' reagent ( $1 \%$ sulphanilamide, $2 \%$ o-phosphoric acid and $0.1 \%$ napthyl ethylene diamine dihydrochloride) was added. Absorbance was read at $546 \mathrm{~nm}$ and percentage inhibition of nitric oxide radical by the oil was calculated using the equation as described in DPPH assay. All measurements were run in triplicates and mean values were calculated.

\subsection{Statistics}

Data were calculated as means \pm SD. Pearson's correction analysis (SPSS15.0 for windows, SPSS Inc) was used to test form the significance of the relationship between the concentration and percentage inhibition. Significant difference was considered at a level of $\mathrm{P}<0.05$.

\section{Results and Discussion}

\subsection{Antioxidant Activity of the Oils}

The neem crude (NCO) and refined neem oils (RNO1) and (RNO2) with activated charcoal and the coloureless de-bittered fraction respectively were examined for radicals scavenging and antioxidant activities using four different assay methods. The percentage inhibitions of the oils were concentration dependent. The percentage inhibitions for DPPH assay are given in Figure 1. At all concentrations $(0.1-0.4 \mathrm{mg} / \mathrm{mL})$ the crude neem oil showed stronger DPPH radicals scavenging activity than the refined oils. Interestingly, the oils activity at 0.2 $\mathrm{mg} / \mathrm{mL}$ and $0.4 \mathrm{mg} / \mathrm{mL}$ were far above average and demonstrated comparable scavenging activity to vitamin C. Unlike in DPPH assay, the oils were less active in scavenging ABTS radicals, while vitamin C and carotene activities were superior to the three oils at all concentrations. However the crude neem oil scavenging activity at $0.4 \mathrm{mg} / \mathrm{mL}$ was above average (Figure 2). 


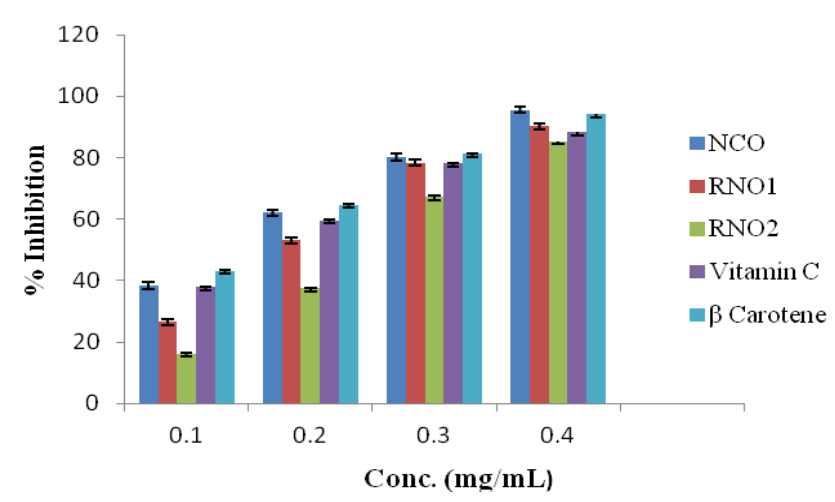

Figure 1. Antioxidant activity of crude and refined Neem oils on DPPH radicals

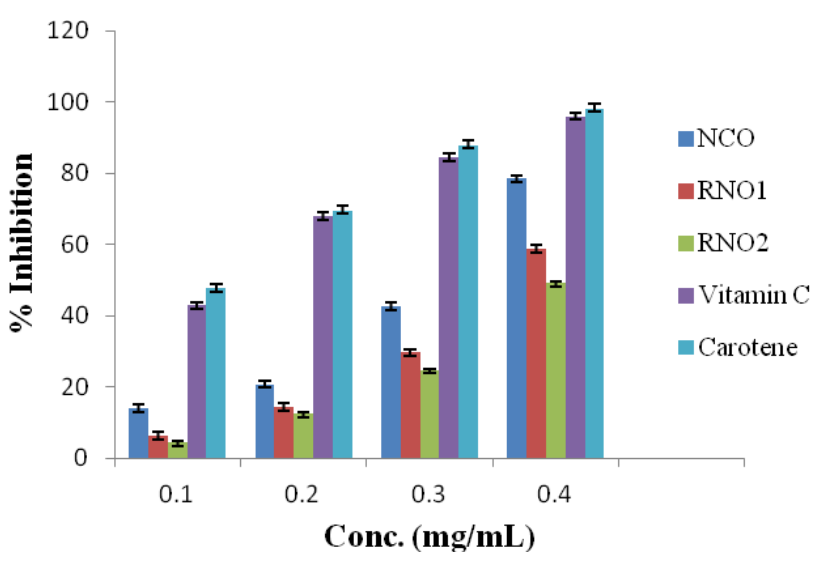

Figure 2. Antioxidant Effects of Crude and Refined Neem oils on ABTS radicals

The lipid peroxide radicals scavenging activity of the neem oils results at concentrations $(0.1-0.4 \mathrm{mg} / \mathrm{mL})$ is shown in Figure 3. The crude neem oil demonstrated more potent lipid peroxide radicals scavenging activity than the refined neem oil and two commercial antioxidants (vitamin $C$ and $\beta$-carotene). At all concentrations (0.1- 0.4 $\mathrm{mg} / \mathrm{mL}$ ), the crude oil displayed stronger lipid peroxide radicals scavenging activity than the refined oil while there is no significant difference $(\mathrm{P}<0.05)$ in peroxide radicals scavenging activity between the crude neem oil and the two commercial antioxidants.

The radical scavenging activity of the crude and refined neem oils at various concentrations against nitric oxide (NO) radicals generated from sodium nitroprusside solution are presented in Figure 4. The percentages of inhibition of the NO radicals by crude neem oil were not significantly different $(p<0.05)$ from the crude neem oil refined with activated charcoal (RNO1), vitamin $\mathrm{C}$ and $\beta$-carotene at $0.1-0.3 \mathrm{mg} / \mathrm{mL}$. Notable is the significance difference at a higher concentration $(0.4 \mathrm{mg} / \mathrm{mL})$, as the crude neem oil nitric oxide radicals scavenging activity was superior, while RNO1 and RNO2 activities were comparable to vitamin $\mathrm{C}$ and $\beta$-carotene.

Previous in-vitro antioxidant studies have noted that DPPH test does not discriminate between types of radical species, but gives rough estimates of radicals quenching ability (Sachdev \& Davies, 2008). Therefore, we studied quantitative and qualitative antioxidant capacity of the oils for suspected antioxidant activity using four radical quenching assays. In the series of the in vitro tests the crude and refined oils of $A$. indica (neem) seeds exhibited significant antioxidant activity by acting as donators of proton or electron in the DPPH, ABTS assays and possessed strong hydroxyl, lipid peroxide (LP) and nitric oxide (NO) radical scavenging capacities. In DPPH, LP and $\mathrm{NO}$ assays, the crude and refined neem oil (RNO1) demonstrated similar radicals scavenging activity to the two positive controls (vitamin $\mathrm{C}$ and $\beta$ carotene). These results are presented in Figures $1-4$, while the $\mathrm{IC}_{50}$ values for the oils are presented in Table 1. 


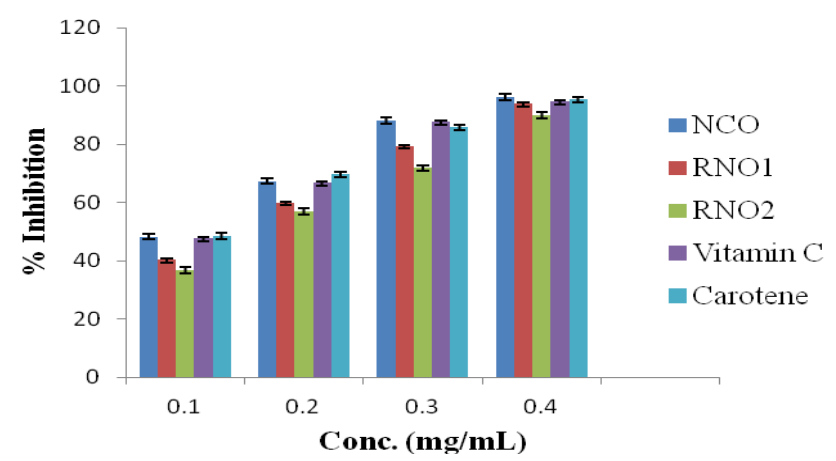

Figure 3. Antioxidant Effects of Crude and Refined Neem oils on Lipid peroxyl radicals

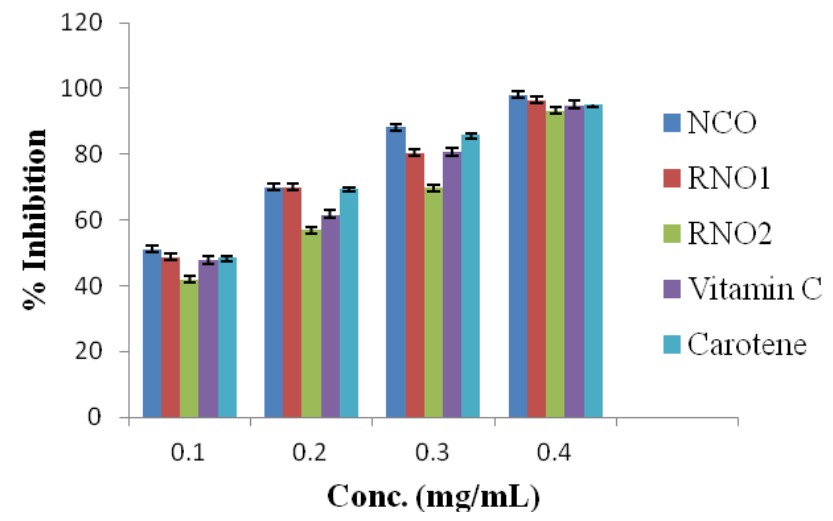

Figure 4. Antioxidant Effects of the Neem oils on Nitric oxide radicals

\subsection{Antioxidant Capacity of the Oils}

The crude neem oil (NCO) and refined neem oils (RNO1 \& RNO2) were able to reduce the stable purple DPPH radicals to a yellow-coloured DPPH-H, reaching $50 \%$ reduction, with $\mathrm{IC}_{50}$ values $1.50 \pm 0.10,1.94 \pm 0.11$ and 2.40 $\pm 0.10 \mathrm{mg} / \mathrm{mL}$ respectively (Table 1 ).

Table 1. Antioxidant capacity of neem crude and refined neem oils $(\mathrm{mg} / \mathrm{mL})$

\begin{tabular}{cccccc}
\hline \multirow{2}{*}{ Activity } & Crude Neem Oil & \multicolumn{2}{c}{ Refined Neem Oil } & \multicolumn{2}{c}{$\begin{array}{c}\text { Commercial Antioxidants } \\
\text { (Positive Controls) }\end{array}$} \\
\cline { 2 - 6 } & NCO & RNO1 & RNO2 & Vitamin C & $\beta$-Carotene \\
& $\left(\mathbf{I C}_{\mathbf{5 0}}\right)$ & $\left.\mathbf{( I C}_{\mathbf{5 0}}\right)$ & $\mathbf{( I C}_{\mathbf{5 0}} \mathbf{)}$ & $\left.\mathbf{( I C}_{\mathbf{5 0}}\right)$ & $\left.\mathbf{I C}_{\mathbf{5 0}}\right)$ \\
\hline $\mathrm{DPPH}^{\bullet}$ & $1.50 \pm 0.10$ & $1.94 \pm 0.11$ & $2.40 \pm 0.10$ & $1.60 \pm 0.13$ & $1.27 \pm 0.12$ \\
$\mathrm{ABTS}^{+}$ & $3.01 \pm 0.20$ & $3.81 \pm 0.12$ & $4.36 \pm 0.11$ & $1.2 \pm 0.14$ & $0.97 \pm 0.30$ \\
LP $^{\bullet}$ & $0.98 \pm 0.01$ & $1.48 \pm 0.22$ & $1.70 \pm 0.04$ & $1.02 \pm 0.04$ & $0.90 \pm 0.11$ \\
$\mathrm{NO}^{\bullet}$ & $0.82 \pm 0.02$ & $0.94 \pm 0.04$ & $1.57 \pm 0.13$ & $1.18 \pm 0.12$ & $0.93 \pm 0.20$ \\
\hline
\end{tabular}

CNO: crude neem oil, RNO1 $=$ refined neem oil with activated charcoal neem oil, RNO2 $=$ refined neem oil with silica gel. Values are mean $\pm \mathrm{SD}, \mathrm{n}=3$. The $\mathrm{IC}_{50}(\mathrm{mg} / \mathrm{mL})$ was obtained from standard curve for each oil and positive controls. The lower $\mathrm{IC}_{50}$ the higher antioxidant capacity. Significant difference was considered at a level of $\mathrm{P}<0.05$.

The antioxidant capacities of the three oils in the DPPH radicals assay were comparable to the commercial antioxidants (vitamin $\mathrm{C}$ and $\beta$-carotene). The three oils antioxidant capacities were similar and less effective in 
scavenging ABTS radicals than the DPPH radicals with $\mathrm{IC}_{50}$ values $3.01 \pm 0.20,3.81 \pm 0.12$ and $4.36 \pm 0.11 \mathrm{mg} / \mathrm{mL}$ respectively, while the vitamin $\mathrm{C}$ and carotene antioxidant capacities were superior to the oils (Table 2). These results corroborated previous reports that the complexity of oils, polarity and chemical properties may lead to varying bioactivity depending on the method adopted (Guerrini et al., 2009).

The crude neem oil, vitamin $\mathrm{C}$ and $\beta$-carotene exhibited excellent antioxidant capacity against lipid peroxide radicals with $\mathrm{IC}_{50}$ values $0.98 \pm 0.01,1.02 \pm 0.04$ and $0.90 \pm 0.11 \mathrm{mg} / \mathrm{mL}$ respectively. However, the refined oils (RNO1 \& RNO2) antioxidant capacities $(1.48 \pm 0.22$ and $1.70 \pm 0.04 \mathrm{mg} / \mathrm{mL})$ were lower than crude neem oil. In the nitric oxide antioxidant experiment, refined neem oils (RNO1\& RNO2) and vitamin C exhibited similar antioxidant capacity and effectively reduced the generated $\mathrm{NO}$ radicals with significant $\mathrm{IC}_{50}$ of $0.94 \pm 0.04,1.57 \pm$ 0.13 and $1.18 \pm 0.12 \mathrm{mg} / \mathrm{mL}$ respectively. It is noteworthy that the crude neem oil displayed slightly higher antioxidant capacity than $\beta$-carotene and vitamin C. Factors like stereo-selectivity of the radicals or the solubility of the oil in the different testing systems have also been reported to affect the capacity of oils in quenching different radicals [30]. Studies have also shown that some antioxidants are good electron donor (active antioxidants) in DPPH assay are inactive in ABTS assay vice- versa (Wang, Wu, Zu \& Fu, 2008). Therefore, the ability of the crude and refined neem oils to scavenge different free radicals in different systems is remarkable. This indicates that the oils may be useful for preventing radical related pathological damage, especially breakdown of biomolecules and DNA by LP and NO radicals that may lead to arteriosclerosis, carcinogenesis and inflammation (Valko, Leibfritz, Moncol, Mazur, \& Telser, 2007).]. Several studies have shown that chronic expression of $\mathrm{NO}$ radicals is associated with inflammation conditions including juvenile diabetes, multiple sclerosis, arthritis, ulcerative colitis (Sathyavathi, Suchetha, Vijay, Ullal, \& Praveen, 2012; Fini, Johnson, Stenmark \& Wright, 2013).

\subsection{Composition of the Oil Extracted}

The GC/MS quantitative and qualitative analyses of the crude and refined neem oils in our previous report (Okoh, Ahmed, Okoh, \& Igwe, 2014), revealed the presence 9 - octadecenoic (oleic) acid (30.42\%), 6 -hexadecenoic acid (11.02\%), palmitic acid (21.51\%), Stearic acid (17.75\%) and methyl octadecanoate (16.88\%) as the dominant compounds. Other important compounds in the crude and the refined oils (NCO, RNO1 and RNO2) were 2-pentanethiol (1.30-5.28 \%), 3, 13-octadecedienol (2.50 - 2.80\%), 2-dodecenal (0.23-3.59\%) and trans-2-decenal (0.42-2.71\%). In the refined oils (RNO1 and RNO2), the 2-pentanethiol content was significantly reduced to 1.30 and $1.37 \%$ respectively. The high content of the monounsaturated fatty acids (oleic, 6 -hexadecenoic acids) and substantial 2-pentanethiol identified in theses oils could be responsible for the strong antioxidant capacity displayed. These results suggest possible synergistic effects of the compounds (Peana, Marzocco, \& Popolo, 2006; Luh, Wong, \& El-shimi, 2007). The findings in this study are in agreement with previous oil studies, that some fatty acids that are mono and polyunsaturated are good natural antioxidant and anti-inflammatory agents (Cockbain, Toogood, \& Hull, 2013).

\section{Conclusion}

This study shows that besides the traditional uses of the plant extract, the crude and refined oils extracted from $A$. indica seeds have good antioxidant potential, and could probably replace synthetic antioxidants in further studies.

\section{Acknowledgments}

The authors are grateful to Management of Federal Institute of Industrial Research Oshodi (FIIRO) Lagos, Nigeria and Govan Mbeki Research and Development Centre, University of Fort Hare, Eastern Cape, South Africa for supporting this research work.

\section{Conflicts of Interest}

The authors declare no conflict of interest.

\section{References}

Anaso, A. B., \& Anaso, C. E. (2001). Formulation of Neem Based Biopectiticides in Nigeria. Challenges before Research and Development Institutions. UNIDO Report, 135-139.

Anokwuru, C. P., Ajibaye, O., \& Adesuyi, A. (2011). Comparative antioxidant activity of water extract of Azadiractha indica stem bark and Telfairia occidentalis leaf. Current Research Journal of Biological, Sciences 3(4), 430-434.

Asekun, O. T., Okoh, S. O., Familoni, O. B., \& Afolayan, A. J. (2013). Chemical Profiles and Antioxidant activity of essential oils extracted from the leaf and stem of Parkia biglobosa (Jacq) Benth. Research Journal of Medicinal Plants, 7, 82-91. http://dx.doi.org/10.3923/rjmp.2013.82.91 
Asuquo, J. E., Etim, E. E, Ukpong, I. U., \& Etuk, S. E. (2012). Extraction, Characterisation and fatty acid profile of pogaoleosa oil. Intl. J. Mod. Anal. Sep. Science, 1, 23-30.

Badmus, J. A., Odunola, O. A., \& Obuotor, E. (2010). Phytochemical and in vitro antioxidant potentials of Holarrhena floribunda leaf. Afr. J. Biotechnology, 9, 340-346.

Camila, C. S., Mirian, S. S., Vanine, G. M., Luciana, M. C., Antonia, A. C., Guilherme, A. L., \& Reinaldo, N. A.(2013). Antinociceptive and Antioxidant Activities of Phytol in vivo and in vitro Models. Neuroscience Journal, Article ID 949452.

Cockbain, A. J., Toogood, G. J., \& Hull, M. A. (2013). Omega-3 polyunsaturated acids for treatment and prevention of colorectal cancer: Recent Advances in basic science. Gut ,16, 135-149.

Fini, M. A., Johnson, R. J., Stenmark, K. R., \& Wright, R. M. (2013). Hypertension, nitrate-nitrite, and xanthine oxidoreductase catalyzed nitric oxide generation: Pros and Cons. Hypertension, 62, e9. floribunda leaf. Afr. J. Biotechnology, 9, 340-346.

Ghimeray, A. K., Jin, C., Ghimire, B. K., \& Cho, D. H. (2009). Antioxidant activity and quantitative estimation of azadirachtin and nimbin in Azadirachta Indica A. Juss grown in foothills of Nepal, Journal of Biotechnology, 8(23), 3084-3091.

Guerrini, A., Sacchetti, G., Rossi, D., Paganetto, G., Muzzoli, M., \& Andreotti, E. (2009). Bioactivities of Piper aduncum and Piper obliquum essential oils from Eastern Ecuador. Environ. Toxicology Pharmacology, 27, 39-48. http://dx.doi.org/10.1016/j.etap.2008.08.002

Luh, S., Wong, S., \& El-shimi, E. (2007). Effect of processing on some chemical constituents of Pistachio nuts. J. Food Quality, 5, 33-41. http://dx.doi.org/10.1111/j.1745-4557.1982.tb00954.x

Mahmood, R. M., Soheila, M., \& Saeid, A. (2008). Radical scavenging and reducing power of Salvia mirzayanii subfractions. Molecules, 13, 2804-2813. http://dx.doi.org/10.3390/molecules13112804

Makhija, I. K., Aswatha, H. N., Shreedhara, C. S., Vijay, K. S., \& Devkar, R. (2011). In vitro antioxidant studies of Sitopaladi Churna, a polyherbal Ayurvedic formulation. Free Radical Antioxidant, 1, 37-41. http://dx.doi.org/10.5530/ax.2011.2.8

Mak-Mensah, E. E., \& Firempong, C. K. (2011). Chemical characteristics of toilet soap prepared from neem (Azadirachta indica) seed oil Asian J. Plant Sci. Res., 1(4), 1-7.

Miller, E. R., Pastor-Barriuso, R., Dalal, D., Riemersma, R. A., Appel, L. J., \& Guallar, E. (2005). Vitamin E su pplementation may increase all-cause mortality. Ann. Intern. Med., 1, 37-46. http://dx.doi.org/10.7326/00034819-142-1-200501040-00110

Mimica-Dukic, N., Dušan, B., Slavenko, M., Dragana, V. G., \& Branka, O. D. (2010). Essential oil of Myrtus communis L. as a potential antioxidant and antimutagenic agents. Molecules, 15, 2759-2770. http://dx.doi.org/10.3390/molecules15042759

Moncol, J., Mazur, M., \& Telser, J. (2007). Free radicals and antioxidants in normal physiological functions and human disease. Int. J. Biochem. Cell Biology, 39, 44-84. http://dx.doi.org/10.1016/j.biocel.2006.07.001

Morten, H., Mygind, T., L. \& Rikke, M. (2012). Essential Oils in Food Preservation: Mode of Action, Synergies, and Interactions with Food Matrix Components. Front Microbiology, 3, 12. http://dx.doi.orrg/10.3389/fmicb. 2012.00012

Murray, A. P., Rodriguez, M. A., Frontera, M. A., \& Mulet, M. C. (2004). Antioxidant metabolites from limonium brasiliene, Naturforsch, 59, 477-480.

Nahak, G., \& Sahu , R. K.. (2010). Antioxidant activity in bark and roots of Neem (azadirachta indica) and Mahaneem. Continental J. Pharmaceutical Sciences, 4, 28-34.

Nahak, G., \& Sahu, R. K. (2011). Evaluation of antioxidant activity of flower and seed oil of Azadirachta indica A. juss, Journal of Applied and natural Science, 3(1), 78-81.

Nweze, E. I., \& Okafor, J. I. (2010). Activities of a wide range of medicinal plants and essential oil against Scedospaorium isolates. Am. Eurasian J. Sci. Res., 5, 161-169.

Okoh, S. O., Ahmed, S. A., Okoh, O. O., \& Igwe, C. C. (2014). GC/MS Constituents and Physicochemical Properties of Crude and Refined Azadirachta indica Seed Oils. Pittsburgh Conference, Symposium and Exhibition on analytical Chemistry \& Applied Spectroscopy, March 2-6, 2014, Chicago, Illinois, USA. http://dx.doi.org/10.3390/antiox3020278 
Okoh, S. O., Asekun, O. T., Familoni O. B., \& Afolayan A. J. (2014). Antioxidant and Free Radical Scavenging Capacity of Seed and Shell Essential Oils Extracted from Abrus precatorius, Antioxidant, 3, 278-287.

Okoh, S. O., Asekun, O. T., Familoni, O. B., \& Afolayan, A. J. (2011). Composition and Antioxidant Activities of leaf and root volatile oils of Morinda lucida. J. Natural Product Communications, 6(10), 1537-1541.

Okujagu, T. F. (2009). Medicinal plants of Nigeria from North East zone of Nigeria. Natural Medicine Development agency (NNMDA), Lagos. 109. Nigeria.

Pasquale, A., \& Saija, A. (2013). Biomolecular characterization of wild sicilia oregano: Phytochemical screening of essential oils and extracts, and evaluation of their antioxidant activities. Chem. Biodiversity, 10, 411-433. http://dx.doi.org/10.1002/cbdv.201200219

Peana, A., Marzocco, S., \& Popolo, A. (2006). Linalool inhibits in vitro NO formation: Probable involvement in the antinociceptive activity of this monoterpene compound. Life Science, 78, 719-723. http://dx.doi.org/10. 1016/j.1fs.2005.05.065

Reinaldo, N. A. (2013). Antinociceptive and Antioxidant Activities of Phytol in vivo and in vitro Models. Neuroscience Journal, Article ID 949452.

Sachdev, S., \& Davies, K. (2008). Production, detection, and adaptive responses to free radicals in exercise. Free Radical Biology and Medicine, 44, 215-223. http://dx.doi.org/10.1016/j.freeradbiomed.2007.07.019

Sadeghian, M. M., \& Mortazaienezhad, F. (2007). Investigation of Compounds from Azadirachta indica (Neem) Asian Journal of Plant Sciences, 6, 444-445. http://dx.doi.org/10.3923/ajps.2007.444.445

Saikat, S., Chakraborty, R., Sridhar, C.Y., Reddy, S.R., \& Biplab, D. (2010). Free radicals, antioxidants, diseases and phytomedicine: Current status and future prospect. Int. J. Pharm. Sci. Rev. Res., 3, 91-100.

Sathyavathi, A., Suchetha, N., Vijay, R., Ullal, D., \& Praveen, A. (2012). Status of Phosphodiesterase, Nirtic oxide and Arginase levels in hypo and hyperthyroidism. Int. J. Res. Pharm. Biomed. Science, 3, 541-544.

Subapriya, R., \& Nagini, S. (2005), Curr. Med. Chem. Anticancer Agents, 5(2), 149-156. http://dx.doi.org/10. 2174/1568011053174828

Tuttolomondo, T., La Bella, S., Licata, M., Virga, G., Leto, C., Saija, A., ... \& Ruberto, G. (2013). Biomolecular characterization of wild Sicilian oregano: phytochemical screening of essential oils and extracts, and evaluation of their antioxidant activities. Chemistry \& biodiversity, 10(3), 411-433. http://dx.doi.org/10. 1002/cbdv.201200219

Wang, W., Wu, N., Zu, G., \& Fu, Y (2008). Antioxidant activity of Rosmarinus officinalis essential oil compared to its main components. Food Chem., 108, 1019-1022. http://dx.doi.org/10.1016/j.foodchem.2007.11.046

Witayapan, N., Sombat, C., \& Siriporn, O. (2007). Antioxidant and antimicrobial activities of Hyptis suaveolens essential oil. Scientia Pharmaceutica, 75, 35-46. http://dx.doi.org/10.3797/scipharm.2007.75.35

\section{Copyrights}

Copyright for this article is retained by the author(s), with first publication rights granted to the journal.

This is an open-access article distributed under the terms and conditions of the Creative Commons Attribution license (http://creativecommons.org/licenses/by/3.0/). 